\title{
DO PEOPLE WANT MORE PARTICIPATION? TENSIONS AND CONFLICTS IN GOVERNANCE IN TIMES OF SCEPTICISM ${ }^{1}$
}

\section{¿Quiere la gente participar más? Tensiones y conflictos sobre el gobierno en tiempos de escepticismo}

\author{
ERNESTO GANUZA \\ IESA/CSIC \\ eganuza@iesa.csic.es \\ PATRICIA GARCÍA-ESPÍN \\ IESA/CSIC \\ pgarcia@iesa.csic.es \\ STEFANO DE MARCO \\ Universidad de Salamanca \\ sdemarco82@hotmail.com \\ Cómo citar/Citation \\ Ganuza, E., García-Espín, P. y De Marco, S. (2017). \\ Do people want more participation? \\ Tensions and conflicts in governance in times of scepticism. \\ Revista de Estudios Políticos, 176, 253-279. \\ doi: https://doi.org/10.18042/cepc/rep.176.08
}

\section{Abstract}

When ordinary people are asked how they feel about politics, negative terms enter into the conversation. In this work we analyse how people build their relationship with politics, to explore to what extent political representation is challenged by either participatory trends or by expert-based governance in citizens' mind. To do this, we use focus groups in Spain, where popular distrust of political institutions rose

1 Esta investigación se ha realizado en el marco del proyecto de investigación «Stealth democracy: Between participation and professionalization», financiado por el Ministerio de Economía y Competitividad (CSO2012-38942). 
dramatically in the period 1980-2012. We analyse the meanings associated with expert-based, representative, and participatory governance models. In this way, the tensions and contradictions in political preferences for one type of institutional design or another are unveiled.

\section{Keywords}

Stealth democracy; participation; experts; representation; political distrust.

\section{Resumen}

Cuando preguntamos a la gente común sobre lo que siente por la política, los términos negativos suelen dominar la conversación. En este trabajo analizamos cómo la gente construye su relación con la política para explorar hasta qué punto la representación política es desafiada tanto por una tendencia participativa como por una tendencia tecnocrática. El trabajo se basa en una investigación con grupos de discusión en España, donde la desconfianza hacia las instituciones políticas ha tenido un incremento extraordinario en los últimos veinte años. El trabajo analiza los significados asociados con una gobernanza dominada por expertos en contra de una dominada por representantes o la participación ciudadana. De esta manera podemos desvelar las tensiones y las contradicciones que la ciudadanía tiene sobre las preferencias por un diseño institucional u otro.

\section{Palabras clave} política.

Democracia furtiva; participación; expertos; representación; desconfianza 


\section{SUMARIO}

I. INTRODUCTION. II. BETWEEN PARTICIPATION AND EXPERTS. III. RESEARCH STRATEGY, METHODS AND SAMPLE. IV. POLITICS: THE THING THAT DOESN'T WORK. V. BEYOND REPRESENTATION? THE ROLE OF EXPERTS. VI. THINKING ABOUT "THE EQUALS": PARTICIPATION AS AN ALTERNATIVE. VII.CONCLUSIONS: DEMOCRACY "TOUT COURT". REFERENCES

\section{INTRODUCTION}

When ordinary people are asked how they feel about politics, negative terms such as dissatisfaction, disenchantment, indifference, apathy, distress or unrest are brought to the conversation and frame any other arguments and complaints. In the popular imaginary politics is enshrouded in a negative aura. We know that this is a well established tendency in Western countries, having existed as a classic debate in Political Science for a long time (Norris, 1999; Pharr and Putnam, 2000; Torcal and Montero, 2006). The accumulative knowledge allows us to recognise the characteristics of people who are disaffected and to what extent this alienates citizens from politics. We can even differentiate political attitudes to highlight what kind of social profiles are more or less inclined to engage in politics. The better educated, younger and postmaterialist citizens usually criticise political elites and institutions, demanding improvement of democratic political processes (Dalton, 2004). After the recent global protests in many western countries, calling for a bottom up political process (Tejerina et al., 2013; Gamson and Sifry, 2013), the question has attracted much more attention.

Democracy needs public support. Against any other way of governing, democracy rests on citizens' preferences. Thus, disaffection gives rise to a second order question; we are not only concerned with who feels or has this attitude, but to what extent disaffection impacts citizen's political process preferences. Do people want more participatory governments or do they want more knowledgeable and expert-like politicians? Do they really want to overwhelm representation as a political process?

Increasing participation in politics is an established trend in Western democracies (Sirianni and Friedland, 2001; Font et al., 2014; Baiocchi and Ganuza, 2016). However, against this inclination some researchers have 
questioned the citizen's support for it. More than participation, the citizenry would be inclined towards a technical and impartial government (Hibbing and Theiss-Morse, 2002). This paper seeks to shed light on this issue by focusing on Spanish citizens' political process preferences. Most literature in Europe finds the compatibility of both trends. For researchers it unveils a problem of inconsistencies in citizens' political preferences. As we will see, our research shows the same compatibility, it is grounded in a will to support representation as a political process guided by a more open (participatory) and professional (expert) government.

The article begins by explaining the viewpoint from which we believe this compatibility makes sense. Secondly, we present our research strategy, based on qualitative methods. This gives us a chance to focus on arguments, so we can follow up on how problems with the current political process are conceived by people and where they would like to innovate. Finally, we examine the arguments in favour of and against participatory or expert based governance in order to shed light on the core question: do people really want to overcome representative political processes?

\section{BETWEEN PARTICIPATION AND EXPERTS}

Disaffection is not a new phenomenon (Easton, 1965; Crozier et al., 1975), however nowadays it attracts a lot of attention due to the acknowledgement of the convergence between a new style of citizenship, more informed and demanding, and an established representative democracy unable to provide satisfactory answers to this new social profile (McHugh, 2006). The emergence of the so called critical citizens (Norris, 2009; Dalton, 2004) has fostered changes in politics. This was the basis of the Council of Europe's arguments (2001) to innovate in political processes at the turn of the new century. This cultural drift of western society has usually been understood as a cultural world that has fostered individual gain and the self (Lasch, 1995). A different influence on current political processes may be expected, depending on how the cultural drift is understood. We can identify two clear tendencies to improve governance: 1) support for more participation (critical citizens hypothesis) and 2) support for more experts in government (stealth hypothesis).

Some researchers think that the cultural drift of Western societies underlines a political openness of citizens who demand alternative ways of political engagement and other institutions (Dalton, 2004). Disaffection would unveil a critical position of citizens in relation to the current political system. Thus, critical citizens widen their repertoire of political intervention, suggesting a preference for a more direct and transparent relationship with rulers 
(Norris et al., 2006; Dalton, 2004). People, it is said, would like to be involved in decision making processes (hypothesis 1). Against this trend, others understand that the cultural drift of Western society has given rise to a gap between citizen's expectations and the achievements of the political system (Stoker, 2006: 68). In a cultural context increasingly dominated by individualist choices, politics, defined as collective choice and action, is unable to produce maximalist answers for every citizen. The problem is that no one wants to be a looser and share political solutions. So, if people are disaffected, it is because they want objective and efficient decision making processes, far from disagreement, which is at odds with the core values of politics (Hibbing and Theiss-Morse, 2002: 143) and demands a more expert-based governance (hypothesis 2).

Since Hibbing and Theiss-Morse (2002) stated their stealth democracy thesis (hypothesis 2), it has been disputed in the US and Europe. Neblo et al. (2010), with different survey questions, showed that American citizens had preferences for other ways of ruling within a deliberative framework. In the UK, Webb (2013), also with different survey questions, showed that the British were more inclined towards participatory mechanisms, even though many people also supported the stealth democracy thesis. But the most striking revelation made by recent research has been the coexistence of both trends. In Finland, Bengtsson and Mattila (2009: 1045) said that many people "prefer simultaneously both more direct democracy and more stealth democracy". For Webb (2013: 767) this overlap covers around 25\% of British survey respondents. In Spain, Font et al. (2015: 159) suggest that there are many who show simultaneous support for some of the three governance principles, including representation.

Besides this confluence, the same factors that explain support for stealth democracy serve to explain direct democracy support in Finland (Bengtsson and Mattila, 2009: 1042). Only ideology, as in US, would explain the differences. Something similar happens in Spain, although education status gains some influence there (Font et al., 2012). When there are no differences among supporters of one or another ideal model, some researchers think about inconsistencies in citizens' preferences in the terms of Bengtsson and Mattila (2009: 1041). Some scholars place the compatibility of both trends within the emergence of the populism ideal, as Webb stated: "For those people who are disillusioned with the rule of elected politicians, there are various alternatives that seem appealing: rule by technocrats, entrepreneurs or referendums are all ways of bypassing the politicians" (Webb, 2013: 768). Even he tries to relativize the support for participatory mechanisms by those citizens far from stealth ideas. When there is a real chance to be involved in a referendum (it was a question in his research), neither those closest to stealth models, nor citizens 
in favour of participatory mechanisms, are "especially inclined to vote" (Webb, 2013: 768). This is something we have been able to observe in public opinion surveys for a long time. If the disaffection process is accompanied by a slight preference for increased political participation, it does not usually imply an increase of current participatory activities (McHugh, 2006). This scenario, positioned somewhere between the real and the ideal, is also shown by Font in Spain. When answering questions about decision making processes, citizens favor participatory principles against expert-based governance. But when questions are related to specific institutional arrangements, expert-based mechanisms have more support (Font et al., 2015: 159).

One way to understand this puzzle would be to think that people don't really want to participate, as Paul Webb (2013: 768) suggests at the end of his work, even against his own evidence: "[the] demand for the principle of greater participation may owe more to a sense of frustration with, and perhaps incomprehension about, the obscure complexities of the political process, with all its attendant noise, conflict and undoubted venality, than to an authentic desire to become involved in the detail of political decision making". This holds with the stealth hypothesis. Another way has been outlined by Font et al. (2015), suggesting that even if the factors behind the different ideal models are different, they may not be antagonistic. In Spain, citizens identify three different ideal models (participatory, representative and expert-based), but the expert-based model had positive correlations with the others (Font et al., 2015: 163).

We propose to deal with the problem of political process preferences from a different perspective. We think that the debate has usually been presented as a zero sum game and it is difficult to obtain good conclusions from it. If people are inclined towards participation, it is expected that they are less likely to accept expert-based government and vice versa. But if recent research shows the compatibility of both trends in survey responses, we suggest that the problem (and the supposed compatibility between critical and stealth hypothesis) could be anchored in a representative framework, rather than in its alternatives. If the expert-based model has positive correlations with participation and representation in Spain (Font et al., 2015), perhaps the problem is the lack of expertise in representative political architecture. If people are inclined to participatory processes, could it point to a desire to open up representative mechanisms? So, the first question to answer would be if people reject representation. And then, to what extent they want to articulate participation and expert-based models with representation, or even if they finally pretend to overcome representative architecture. Our hypothesis is that people want to reform current political processes through more open structures and more expertise in decision making processes, rather than overcoming current institutional settings. 
We think that the questions quoted above are not easy to answer by applying the same techniques that have been used to study this puzzle. We already have good explanations about who is inclined towards expert-based governance or who is involved in participatory and political activities (Webb, 2013; Bengtsson and Mattila, 2009; Font et al., 2015). But the debate about the meaning or boundaries of the different ideal political processes in citizens' mind is still open. In order to deal with it, we have drawn on a qualitative strategy based on seven focus groups to explore how people make sense of political processes in Spain. The research was conducted in 2011. In this way, we can complement the work carried out by Font $e t$ al. (2012; 2015), as well as that by Hibbing and Theiss-Morse, which originally endeavoured to gain a deeper understanding of survey questions through the use of focus groups. We have followed the same strategy, with questions that are very similar to those of Stealth Democracy focus groups, both in subject matter and in quantity.

Spain makes for an interesting place to study this issue. As many other South European countries, two of the most salient features of Spanish political culture have been distrust in the political institutions and indifference towards politics. Popular distrust facing political institutions followed a dramatic upward trend in the period 1980-2012 (Torcal, 2014). Moreover, the Spanish adhere to a profile of low interest in politics and a relatively low perception of internal and external political efficacy (Bonet et al., 2006: 118). In contrast, the preference for democracy is very high (Torcal, 2014).

The interest of Spain also lies in its singularities regarding political process preferences. One of the more striking elements of research on this topic has been the simultaneous support for participation and expert-based governance. In Finland $70 \%$ of people agree with direct democracy, but they have a similar support of the stealth democracy index ${ }^{2}$ as Americans (Bengtsson and Mattila, 2009). Spain emerges in this research context as a pro-stealth democracy country (Font et al., 2015: 159) "with only 1 per cent of the population disagreeing with all four stealth democracy items [7\% of Americans and $11 \%$ of Finish] and 40 per cent expressing some agreement with at least three of them (compared to 26-27 per cent in Finland or the U.S.)". In contrast, when people are asked about their preferences for participatory mechanisms in decision-making processes the result has usually been high (Mota, 2006). Even

2 The stealth democracy index set up by Hibbing and Theiss-Morse is based on four different items: 1) officials should stop talking and they should start to act; 2) compromise means selling out own principles; 3) government should be run by experts or 4) businessmen 
when people are asked to situate themselves onto a political process scale, from 0 to 10 , where " 0 " means that "citizens should make all political decisions" and "10" means "politicians should do it", Spaniards score 4,5 while Americans 6,3 (Font et al., 2012).

Spain unveils strong political tensions around the ideal decision making models. So, the research can help to illuminate this paradox and we may be able to get closer to the political meanings of participation and experts in a context characterized by strong political disaffection. Is it really true that people are searching for ways of bypassing politicians, but don't have a desire to become involved in the detail of political decision making?

\section{RESEARCH STRATEGY, METHODS AND SAMPLE}

We already had data on the preferences for different types of political processes, so we designed a research strategy based on focus groups. They are useful to interpret and contextualize previous survey results. Focus groups are a good methodological strategy to generate in-depth information on a given topic (Morgan, 1996). As a situated talk (Hydén and Bülow, 2003: 320), focus groups allow the observation of the processes through which participants share and construct their own positions and make sense of themselves as a group (Munday, 2006). Focus groups are far from being a natural encounter amongst friends, but participants engage in conversations and they make sense of common values, deep differences, assumptions and common understandings about themselves and the phenomena (Munday, 2006: 100). The discussion in a focus group is not just the sum of separate individuals; participants query each other (Morgan, 1996: 139). From this perspective, this research tool allows for the creation of an interactive and communicative event, from which "common ground jointly established in the conversation is not given from the opening stage of the conversation, but is rather something that has to be re-established through the contributions the participants make" (Hydén and Bülow, 2003: 316). As suggested by Bryman (2001), focus groups provide the opportunity to study how individuals jointly construct and give meaning to singular phenomena. Dynamics of conversation are the most relevant type of data we extract from focus- groups (Kitzinger, 1995).

The focus groups were conducted in the first half of 2011. The sample of focus groups was intended to reflect different political, social and demographic profiles. We wanted to represent a variety of profiles which were relevant to understanding contrasting views of political processes. Thus, we selected groups with a high political profile and groups with a lower 
political profile, because we already knew that political experience was a relevant factor evaluating some types of processes (Font and Navarro, 2013). We also knew that ideology could be a relevant factor (Bengtsson and Christensen, 2014; Font et al., 2012). Focus groups consisted of 68 people. They were internally homogeneous in terms of political background (high/low political profile). The sample of focus groups was based on the idea that different socio-political positions may produce different discourses on alternative political processes. As Table 1 shows, the sample of focus groups included a variety of socio-political profiles. On the one hand, groups of activists (highly politicized profiles of militants, sympathizers and members of political groups) were selected. On the other hand, the remaining groups consisted of non-activists (low politicized, no members, militants or loyal sympathizers of political parties). A variety of social positions in the form of socio-economic status (age, education and social class) complemented the focus group frames.

Table 1. Final sample of focus groups

\begin{tabular}{ll}
\hline Acronym & Features of the participants \\
\hline FG1 & Elda (Alicante), 2011 \\
Right wing & Militant, sympathizers or voters of right- wing or \\
supporters & conservative (Partido Popular) \\
& Liberal professions (nurse, doctor, lawyer, public officer) \\
& University level education \\
& 8 (5 men and 3 women) \\
& 25-40 years old \\
\hline FG2 & Zaragoza, 2011 \\
Upper-Middle- & Businessmen and women, liberal professions such as lawyer, \\
class professionals & architect and economist \\
& No political activism \\
& University level education \\
& 6 (mixed) \\
& 30-55 years old \\
\hline FG3 & Madrid, 2011 \\
University & University students \\
students & Psychology degree and other social sciences \\
& No political activism \\
& 6 (mixed) \\
\hline
\end{tabular}




\begin{tabular}{|c|c|}
\hline $\begin{array}{l}\text { FG4 } \\
\text { Retired working } \\
\text { class men }\end{array}$ & $\begin{array}{l}\text { Conil de la Frontera, } 2011 \\
\text { Retired workers (ex- workers in agriculture, fisheries and } \\
\text { public services) } \\
\text { No political activism } \\
\text { Medium and low education } \\
6-10 \text { men } \\
\text { Over } 65\end{array}$ \\
\hline $\begin{array}{l}\text { FG5 } \\
\text { VT Students }\end{array}$ & $\begin{array}{l}\text { Seville, } 2011 \\
\text { Vocational training students } \\
\text { Informatics and Computing degrees } \\
\text { No political activism } \\
6 \text { ( } 4 \text { men- } 2 \text { women }) \\
18-20 \text { years old }\end{array}$ \\
\hline $\begin{array}{l}\text { FG6 } \\
\text { Left-wing } \\
\text { supporters }\end{array}$ & $\begin{array}{l}\text { Getafe, } 2011 \\
\text { Militants, sympathizers or voters of leftist parties (Socialist } \\
\text { Party- PSOE or United Left-IU) } \\
\text { White-collar workers and liberal professions } \\
\text { Further and higher (university) level education } \\
7 \text { (3 women and } 4 \text { men) } \\
\text { 30-55 years old }\end{array}$ \\
\hline $\begin{array}{l}\text { FG7 } \\
\text { Social activists }\end{array}$ & $\begin{array}{l}\text { Córdoba, } 2011 \\
\text { Neighbourhood organizations and school parents' } \\
\text { associations } \\
\text { Participants all involved in organization's management } \\
8 \text { ( } 3 \text { women and } 5 \text { men) } \\
30-50 \text { years old }\end{array}$ \\
\hline
\end{tabular}

Source: own elaboration.

The "activist" was understood as a person who belonged to a political organization and had actively participated in it (three groups). Non activist was the person who did not belong or participate in organizations (four groups) which are considered political (parties or social movements). We did not take into consideration whether the participant votes or not. We decided to introduce a sample of conservative and left-wing militants. We also added a group of members of neighbourhood organizations and school parents' associations, as they are the most common social organization, very institutionalized in most Spanish cities. The two groups of students (VT students and university students) were sought to bring different youth profiles with varying social projections (two different class-positions). They weren't members of any political 
organization. In contrast, the group of retired working class men represented a lower educational profile, a middle-low income and an elder generation. In contrast with students and working class men, the group of middle-class professionals was composed of people who were well-off economically and educated to a high level. The purpose was to contrast the different and common axes of discourse by comparing different groups and profiles.

Participants were contacted with the support of a research cooperative, and through the researchers' personal and professional contacts. Locations (cities) were chosen for their accessibility in order to form target groups in that specific area. For example, the right-wing groups were organized in Alicante, a city where Partido Popular (the right-wing party) used to have an electoral majority. Sessions were held in hotels, a tennis club, a seniors' community centre, a research centre, university rooms, etc. The groups did not have directive moderation, and they were conducted with a script similar to that used by Hibbing and Theiss-Morse (2002), which included questions about the political system and process preferences (see the Annex). The debates, which were recorded, lasted an average of an hour and a half.

The emergent conversations of the focus groups were transcribed and coded, assisted by the software Atlas-ti ${ }^{\circledR}$. An initial thematic analysis (Boyatzis, 1998) was developed. Our unit of analysis was each focus group (which had a number of ideological conditions, socio-professional status, age and territory). The results were interpreted in light of the interactions which had taken place within groups. Focus groups not only provide opinions, but also different dynamics of interaction, including direct and subtle changes of opinions (Smithson, 2000). Summaries were written up, interpreting group discourses and the references which the participants reported on the topic. We will present the findings in the following sections, showing the main traits common to the groups, as well as any emerging contradictions and contrasts between them. The groups were not forced to reach any consensus, so discussions did not end with a common vision of the group.

\section{POLITICS: THE THING THAT DOESN'T WORK}

All focus groups started with the same question, posed by researchers: "What do you think about the political system in general?" The immediate reaction in all groups was negative: apathy, dissatisfaction, frustration, anger, fatigue, etc. The thing that doesn't work is related to the communication between the political system and society; people feel that they are not able to put their demands into the political system. Something malfunctions with the political channels. One of the activist participants in Cordoba stresses this 
point: "the bases of the system are good, but it lacks communicative channels between citizens and politicians". The problem with democracy has to do with the connections between politics and society, not with democracy itself. The desire to have democratic processes is indisputable; criticism emerges when participants specify what they mean by democratic connections between politics and society, but democracy, as an ideal type, is a common place. Democracy is a basic cultural ground, even if these two job training students, quoted below, do not find any attraction to vote:

P1: This system, personally, doesn't satisfy me, but I don't have any particular idea why. Ever since I've been able to vote, I've never done it, I can't find any political party fit to represent me. This, I think, is a problem. It shouldn't happen in a good system.

P2: It's true, I agree with him. The system doesn't satisfy me, but it's not completely wrong, because I see worse things elsewhere.

(FG5, Sevilla).

What we can learn from the focus groups is that people's political beliefs are framed in a critical and concerned schema. But this frame is not formed by negative irrational emotions and feelings of detachment; it is formed by opinions and debates about the performance of the political system and how institutions are designed. Political dissatisfaction is rooted in a very simple statement: if we live in a democracy, we should have democratic political institutions. This is what leads people to discuss the pros and cons of political process alternatives, the place of experts and participatory mechanisms, but always within the current institutional framework. This reformist spirit evidences a conflicting path between the political imagery of participants and the democratic development of political institutions. For example, participants in the left-wing activist group discussed how institutions were deficient, particularly the party system which was seen as non-democratic, "The party system... I see it as irreplaceable. But, of course, within parties there is no democracy, in any of them. I speak from my experience. I think we are treated as non-adult citizens. Parties fear, at this stage of democracy, open lists, they fear being linked to the territory. They look up to the "priests" who decide the electoral lists. This is my view". These, or other similar arguments, calling for closer relations and proximity of institutions, appear in all focus groups. They all fit in with the "critical citizen" frame, as people want to open political institutions. But no one seems to reject representative arrangements.

Regarding these connections between the political system and society, we find two contrasting positions in focus groups. On the one hand, in some groups, participants discuss mainly the attributes of the political class, 
hampering the connection between politics and society. Representatives, for a variety of reasons, do not represent properly. They do not capture and deliver popular demands properly. We call this discourse the "failed messenger problem", since discourses focus on the (critique of the) attributes and qualities of politicians as elected representatives. On the other hand, in other focus groups, participants focus mainly on the design of institutions and political processes. We call it the "failed machinery problem". The machinery problem embraces the discourses about the design of political processes, implying the advocacy for other types of political processes.

Participants in our focus groups show mixed arguments; however, some groups privilege the first discourse, and others tend to the second. We can say that those groups formed by participants with higher level of activism tend to discuss the machinery problem, while groups with less political background tend to focus on the messenger problem.

Graph 1. Representation of critical discourses toward the political system

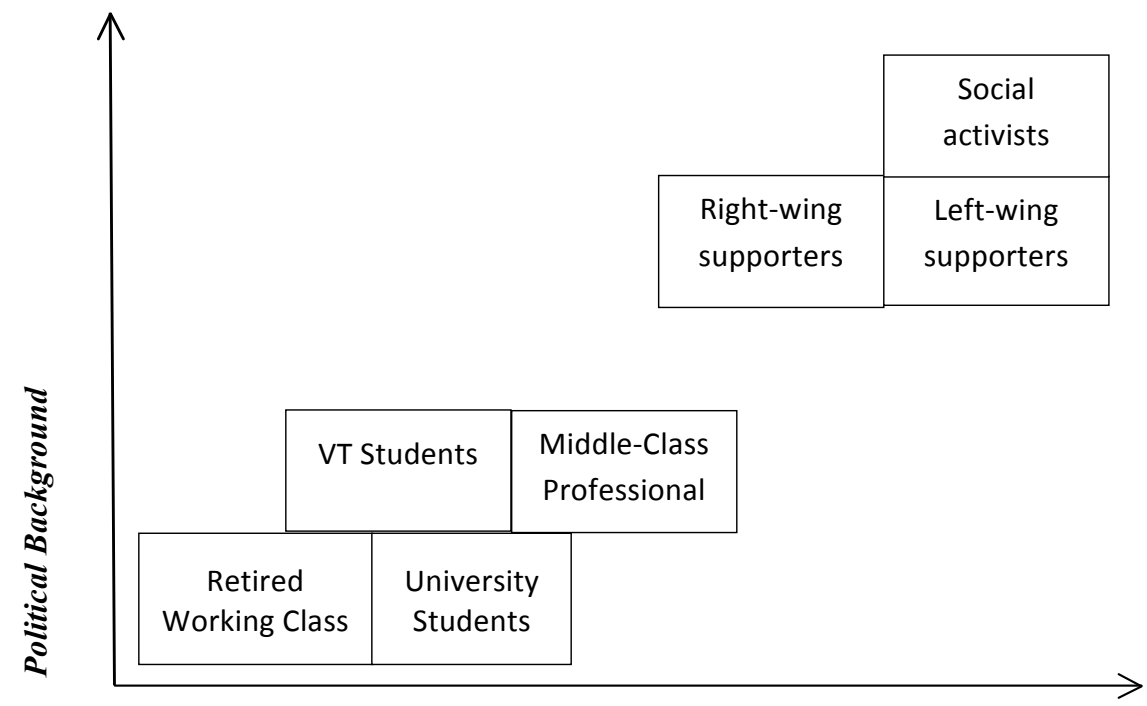

From Messenger to Machinery

Source: own elaboration.

Non-activists were selected taking into account the low political profile of participants (non-militants of parties, social movements or organizations 
with a strong political profile). For example, university students who were studying psychology were asked not to have any membership in political organizations. When they met and were asked about the political system, they remarked on the flaws of politicians as the main problem. They were worried about the performance of these political actors. They do not act properly; they do not make good decisions. They do not deliver their promises. So they do not represent properly popular demands. The messenger, somehow, does not work.

P1: But then the problem is not the system but people...

P2: I think people are the problem. In my view, you vote and then you can complain (...)

P3: You can vote for someone who stands for some things and then he or she does not deliver what they have promised... You say you will do some things and then you don't. Or you don't have a fixed policy direction, so it can vary depending on the events ... These changes [in the political direction] also influence people in a way that makes them reject this political system...

P4: Politics have never been well in Spain, they have never been well...

P2: But there have been politicians who had a more marked direction...

P5: Politicians themselves have to adapt... they should be flexible... and I think that ultimately politicians do not adapt to the context, they do not know make good...

(FG3, Madrid).

In contrast, political activists and party supporters privilege the discussion about institutions and their design. They talk about the system machinery. For example, we can identify this pattern in a group of members of neighbourhood and school parents' associations. These activists criticized the political system in a long conversation on the democratic attributes of current political processes. As can be seen in the following paragraph, some participants criticize the qualities of politicians (the hypothesis of the messenger); but they also deal with the qualities of political processes (the hypothesis of the machinery):

P1: I do not like how it works [the political system]. I had great expectations for many years. But I think there is a lack of real democracy in many of the institutions. There is no reception from below [no bottom-up processes], from the level of participation of people in the streets. Politicians do not listen to the people in the street. There should be a culture in the political system that, somehow, leads to channel all those demands... and it does not work. More or less 
we are on the level of participation in elections every four years or... vote and, later, maybe the right to complain (...)

P2: Things are really serious now. Politicians with their official cars... they do not pay attention to the people. In my view, this will end very badly... I think you have to live with the people, fighting for the people. People have chosen them, and they should be ready and willing to work for the people, not people working for politicians (...). I also think that people should participate more. And to participate more means that politicians need to let it happen... P3: I think that there is something that has failed in the democratic process: the foundations are good; but I think that it lacks the communication channels between the public and the political class. That is, there is a huge distance, caused by whom? I do not know. But, certainly, I do not know how to channel all the demands and... as a citizen or as a member of an association, how to channel the real interests of real people. Channel those demands so that they have an effect.... So, I don't think it's so much a question of the political system itself, which is actually democratic...

(FG7, Córdoba).

There is something wrong in the machine. For these participants, it is not only a matter of the attributes of politicians. They suggest that there is a problem of "communication channels" and there can be alternatives in terms of political processes. They talk about participatory processes. The high political background of these participants, their engagement with local politics trough civic organizations, and even their knowledge of local participatory institutions make them prolific at criticizing the design of political processes. They know the machinery of local politics and they are familiar with political institutions. They discuss mainly alternative processes to fix "the machine". When they do it, they never think about an alternative to the representative system, but in reforming it from a participatory framework.

\section{BEYOND REPRESENTATION? THE ROLE OF EXPERTS}

The idea that dissatisfaction with democracy can go beyond representation is usually portrayed as lack of knowledge and "frustration with the obscure complexities of the political processes" (Webb, 2013: 768). The emergence of populism is usually rooted in this schema. We can't reject that the populism logic is present in people's arguments, if we understand it as an opposition between elites and people (Laclau, 2007). In our focus groups participants articulate a collective identity around "they" vs. "us", where the elites 
are made up of politicians and the "we" is the people, citizens. To what extent can we say that it brings with it simplicity to politics? Focus groups allow us to trace people's arguments back to the origin of the problem.

People are really upset with politicians and political parties, but they never imagine a political design without them, as this left-wing participant says: "The political party system is irreplaceable". The problem is what political theory calls "cartel party" (Katz and Mair, 1995), that is, the reproduction of political elites as a social group, where politicians boost and reproduce their self-interested action. This "cartel" grammar would make them unable to perform their main task, that is, in words of one of the upper middle class participants, the "solution of the country's problems". This argument encourages participants to discredit the political class in general; it feeds the anger against politics, because if they are busy with their affairs, they disconnect politics from the "world of everyday life".

Most people's criticism against politicians and political parties stem from this "cartel" grammar. Hibbing and Theiss-Morse (2002) suggested that one of the main arguments to support stealth attitudes was the idea people have about political competition. Rather than recognize the complexities of achieving agreements, people preferred to think that parties artificially promote differences, as if we could reach agreement easily among different persons and values. In our focus groups people's background is different; they perceive the usual competition grammar among political parties as a competition of the ruling class, fighting for the public resources and customers (instead of citizens), rather than a competition of different beliefs and values about common resources. If, as young persons says (VT students group), "politicians in the Parliament never agree", people don't think that politics is an easy affair. They are "tired of the continuous squabbles among politicians... to destroy the opponent instead of trying to reach agreement", as one participant in the right wing group concluded. The problem lies in the party structures that encourage patronage within the party, as one of the left-wing participants pointed out: "The problem starts with the electoral lists, which are drawn up by the boss. Business as a politician depends on your obedience to the party's leader. This is political despotism, but not because of parties, but people who are in the parties". The criticism, again, does not imply a desire to suppress political parties, rather the way they work. In fact, there are always references to good politicians and a direct recognition of political parties as a key institution. A leftist activist brought forward to the discussion that, "at political level, at local level, in unions etc., I think that there are people working, and doing it very well, who see politics as a service to the public. There are many! But, unfortunately, the Gürtel case [a corruption case], or those cases of corruption in Andalusia outweigh this in the public opinion." 
However the debate here (the complexity of politics) revolves around the expert issue as if they could offer a solution. Stealth hypothesis supporters were right to stress the importance of the issue, because experts, as an ideal meritocracy body in citizens' political imaginary, hold for all the "good" attributes necessary to effectively rule for the community: "They can make decisions efficiently, objectively and without disagreement" (Hibbing and Theiss-Morse, 2002: 143). But meritocracy, for the participants in our focus groups, is good because politics is a complex matter for citizens, not as a way to underline politics as suggested in Stealth Democracy. Just as many wrong attributes of politicians are connected to meritocracy (lack of professionalism, knowledge, skills), all focus groups discussed the problem of experts and their role in politics at length. That is why young people (VT students), for example, wonder about "the extent to which it is not a requirement to have specific knowledge in order to perform political responsibilities".

Hence, participants frequently conceive the ideal politician through expert qualities. As one member of the right-wing activists explained: "The important thing would be that the politician is the expert, it's what we've talked about, excellence and qualification. If one is an expert in economics, I do not want him to be minister of education. I want him to be the finance minister." If technical knowledge is something seen as necessary to perform political functions, participants think that meritocracy, and the principle of distinction linked to it, should therefore be part of the political profile. As a member of the left activist group argued, "I think that politics is one of the professions which require the most expertise in all aspects, that's to say that in politics only the wisest people should govern". Expertise seems to be a political guarantee for citizens in a complex world, but if politicians fail or they are not good enough, should experts rule? Should they replace the parties and politicians as the stealth hypothesis suggest? In the groups, this issue always gave rise to a sharp debate around the role that technical experts should play in government.

The discussion was always guided by a confrontation between a "necessary technical knowledge to rule" and "people's right to be elected for ruling". The tension was strong, but discussions gave priority to the latter, even if most agreed that merit is central in a political career, as this exchange in the rightwing group shows:

P1: There must be representatives, but well-qualified representatives. As for myself, I am ashamed to see the president of my country get nervous when someone speaks English to him.

P2: But Ivan, why do we demand qualification from our politicians and not from the citizens? 
P1: What I want is that those who govern us have a minimum guarantee, because if the minister of economy knows nothing about economics, chaos sets in. Okay, representatives yes, but qualified.

(FG1, Alicante).

We can observe this pattern in all groups. At first politics is associated with the knowledge of experts, because of world complexities. But as the debate advances, participants start to think around the meaning of democracy, that is, the right of each to rule regardless of their origin. At the end, from the left-wing participants ("experts can help, advise decision making process") to upper middle class ("Politics takes more than professionalism. You need to have a political concept and experts don't have it"); or university students ("You cannot make decisions about people if you haven't been chosen to do so. You can give information as an expert"), the problem is that politics often requires political and not technical decisions, so political decisions should be made by someone elected. Far from rejecting politics, in the conversation the technical issue reminds participants of the importance of the political grammar. A good politician would be someone who knows how to do their job well. Experts aren't ultimately seen as an alternative, but "expertise" is a fundamental part of a good government. Dealing with this issue is a cornerstone in citizens' political imagination.

We don't find big differences across groups around this issue. However in highly politicized groups, participants made a clear distinction: experts are subordinated to politicians. Experts are considered "advisers" ("asesores"), "technical staff" or public servants. Their role is to advise politicians and support them so that public policies are of a high quality. This vision is shared by social activists, left and right wingers. Participants in groups of non-activists show a wider variety of positions. There are those participants who do not develop the question further (working-class pensioners), those that show internal debate and contradiction (training and university students), and those who share the activists' understanding (upper middle-class professionals). Some participants in non-activist groups rely on the discourse that experts should have a stronger voice in political processes and decision-making. Other participants defend the subordination relationship mentioned above. They show a plurality of discourses which is not present in highly politicized groups, although ultimately they are not confident that a more prominent role of experts in government would make a positive difference. 
Graph 2. Representation of positions regarding experts*

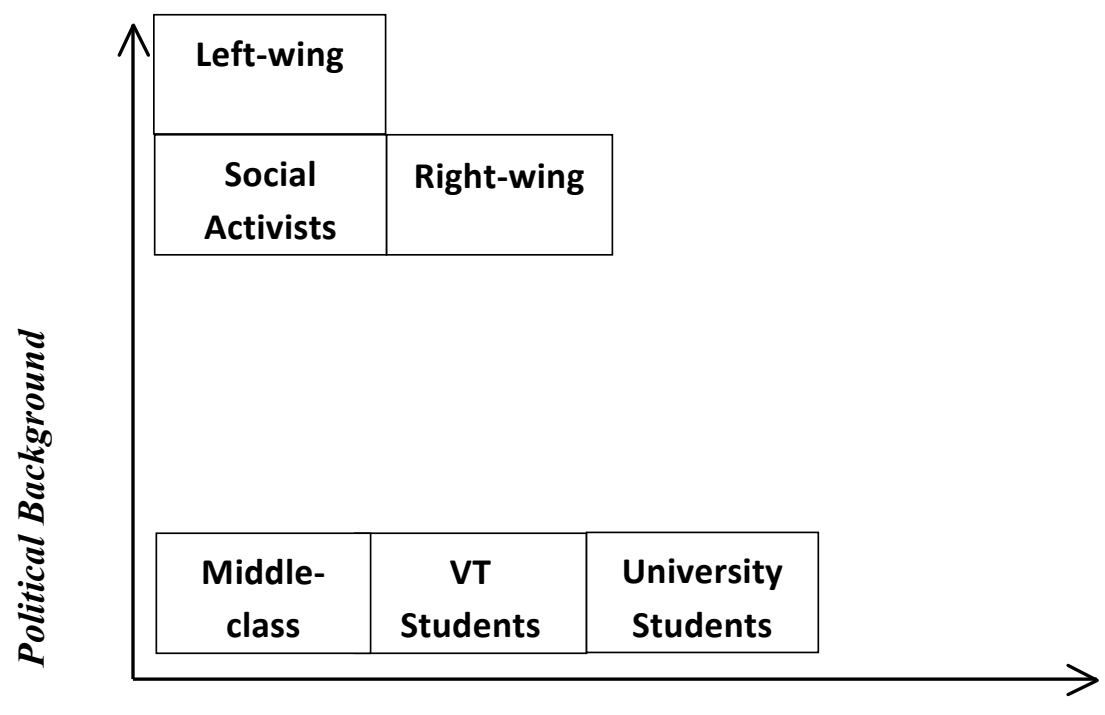

From subordinates to decision-makers

Source: own elaboration.

\section{THINKING ABOUT "THE EQUALS": PARTICIPATION AS AN ALTERNATIVE}

We can say that we live in a participatory age. "Political participation today occupies an exceptional position as a privileged prescription for solving difficult problems and remedying the inherent flaws of democracy" (Baiocchi and Ganuza, 2016: 3). Within this context scholars have wondered if participation is a real alternative in the citizens imaginary as supporters of critical citizens hypothesis have suggested. When participants are asked to think about the feasibility of a participatory model of government they doubt strongly. No one questions the normative background linked to democracy, which is based on the idea of people ruling, but the feasibility of applying the ideal. Here the problems with politicians are taken to society as a whole. Society will then become the cornerstone of the current political crisis. 
People have an underlying view that society is partly responsible for the degradation of the political system. The argument is quite consequential, because if politicians are corrupt and they rule guided by particular interests, it is because no one pays attention, it is because of society. In public discourse, the ultimate blaming of the entire society prevails: "it is the people who are ill and corrupt", a participant in the retired people's group said, getting the approval of the rest. This socialization of the political responsibility balances the criticism towards the political class. One participant in the upper middle class group made the point that, "In any political system, even in those that are not very extreme, in theoretical terms, all regimes have very good things. What happens is that it's people who put them into practice, right? That's the problem in the end." In the group of neighbourhood activists, ideologically contrary to the former group, someone arrived at the same conclusion, "I still think we're not disenchanted by politics, we are disenchanted by some politicians, those who have damaged the overall image of something as magnificent as politics." The negative image of the society itself makes it really difficult to imagine any participatory alternatives to the current political crisis; these will always face individual narrow-mindedness, passions and interests.

The arguments among participants are embedded in the same questions which guide the criticism of politicians. Ordinary people, in the face of political participation, would be unable to work together for the common good and to reach political agreements at the expense of particularistic interests. Many of the problems which targeted the political elite are dumped on society as a whole. If world complexities render expertise an important issue in politics, the same underlines participation. The point is the lack of education, information and civic competence which Spanish people supposedly display in the political arena. For the group of retired working-class men, it seems clear that "People are not ready to make decisions, because there is no education and culture. And that's what happens to people." It is not just a matter of old generations. For younger students (VT students), the perception is similar, "as people lack knowledge, they [politicians] conceal relevant issues to us". Even in the group of neighbourhood activists, who are the most politically confident and demand active participatory policies at municipal level, participants share the same argument: "Yes, the level of citizen competence, that is still very low. We are talking of civic competence..."

It is not only an abstract idea about people; all participants discussed widely the reasons behind this framing with pragmatic examples. All focus groups put in motion a metaphor of direct democracy in assemblies making reference to what we have called the property owners' council syndrome ("el síndrome de la comunidad de vecinos"). Property owners' councils are 
a typical Spanish form of managing horizontal property. The building normally has a meeting a couple of times per year to decide the needs and problems of the community and, specifically, the shared facilities. These councils are mandatory by law. For a member of the upper middle class group, "If you have the opportunity to go to a meeting of a neighbours' community ... People go there with two lawyers! And they just insult each other: it's a frenzied show. That's what would happen in this country if we could all have a say in politics." Likewise, in the left activist group, a participant references the property owners' council syndrome, "Look, here there's just a few of us and there are two who talk a lot. I'd love you to see a meeting of my neighbours' community, it's unbelievable! Imagine a hundred people deciding. I think we need representatives, there must be some sort of delegation." The argument is that people's quarrelsome, egoistic and low civic competence somehow renders society ill-equipped to have a central role in politics.

If participation is not a real alternative to the current political system, participatory processes are not rejected at all; at least, the idea of having a voice in a representative framework. Even if politicians were good enough, even if politics should be ruled by politicians and experts should advise them, people in democracy should also have a voice in ruling. Here the literature confuses taking part in the daily task of ruling (Webb, 2013), something people reject, with having a voice in public policies. In our focus groups, when people talk about participation they have in mind that people should at least have a voice in key legislation. All focus groups made proposals linked to participatory and deliberative politics to bridge this gap between "politics" and "society". For example, in the group of neighbourhood activists, there was an abstract idea somehow shared by most of them, "I think there's been, for such a long time, a lack of real democracy in most institutions. There is no notion of reception from below, from the grassroots". This frame is a reference in the left-wing and activist groups, but it also appears among young students. The rest of the groups stressed continually the need to reform the communicative channels between the state and society, as one right-wing participant pointed out: "the important things, those which affect everyone, have to be decided by all, not only by political parties".

The differences among groups have to do with the procedures and tools discussed. It may be the difference already pointed out by Webb (2013) between dissatisfied vs. stealth democrats, and which we can find in Font's research (et al., 2012). The former are inclined towards more deliberative reforms, while the latter have preferences for more aggregative ways of participation (referenda). In Spain, the former would be represented by left-wing citizens and activists, while the latter would be conservative citizens and 
non-activists. Here we find the key to why some groups prefer a referendum whilst others are inclined to public debate mechanisms (García-Espín et al., 2017). Nevertheless, within this reformist approach, we found a public desire for setting up new ways of political grammar within a representative system, based on public dialogue, in order to foster civic skills, but mainly to expand democratic attitudes. Transversal to all groups is the demand to foster the "voice of people" and "the readiness to listen" by institutions.

\section{Graph 3. Representation of discourses on participatory democracy}

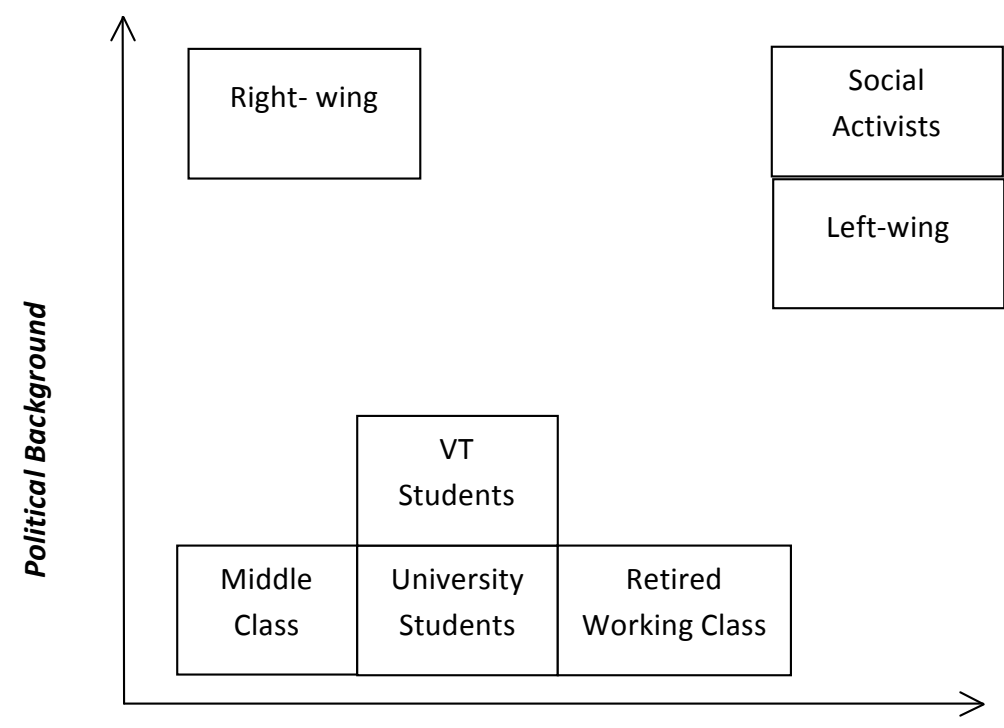

From Aggregative to Deliberative

Source: own elaboration.

There is a general view that important decisions need some involvement from society, from right to left-wing militants and across socioeconomic positions. In the group of right-wing voters a vibrant debate took place, "Are we in a real democracy or a democracy where we vote ... simply choosing some representatives who govern us for four years following their ideals? Ideally, I would make it a condition that plebiscites establish the laws. For me, this would be the ideal government". A peer in the group replied that "in big issues, when reforming important laws... they should consult the people". For one of the participants in the group of professional training students it 
was clear, "Relevant decisions? By urban referendum", and a participant in the retirees' group proposed exactly the same, "Why don't you ask the people? By referendums or in meetings..." Thus, the criticism against politicians begins to make sense through an open reform of political parties as collective institutions which should be linked to society. The idea of communication and participation, without taking the power, leads citizens to envisage political reforms within the parties: open lists, changes in the electoral system, the bonding of representatives to the territory and their population, the limitation of terms, referenda on key issues, internal democracy in political parties, etc. People demonstrate a desire for greater popular control over political processes and for embedded types of political representation, but no one wants to overwhelm them.

If, at the onset, the participation in our focus groups thought about expertise as something compatible with representative institutions, now we can see that for them participation only makes sense as part of a representative framework. No one searches alternatives beyond representation. This unveils the conundrum that people are faced with when dealing with their preferences about political processes.

\section{CONCLUSIONS: DEMOCRACY "TOUT COURT"}

According to our focus groups, we can understand the frustration with politics. Politicians are bad, experts cannot replace them because politics should be performed by elected representatives, and citizens are incompetent to rule and to elect good politicians. This political vicious circle feeds the citizen's political imagination. The problem of the political system is, finally, a cultural issue embodied in a crisis of values and civic competence. This reference appears clearly in leftist groups, which include people engaged in associative movements, who support the participatory experiences from an educative perspective. This is because they are more inclined to deliberative devices rather than aggregative ones, such as referenda (García-Espín et al., 2017).

The debate about political processes in our focus groups unveils that citizens' direct participation is not perceived as a clear alternative. People do not want to get involved in the detail of political decision making, as suggested by Webb (2013). But it does not mean that people do not want to participate at all; citizens want to be heard by politicians, and they want to have a voice in public policies. The apparent contradiction between stealth and participatory attitudes unveils a complex scheme for politics. If Spaniards score the highest in the stealth democracy index, whilst at the same time most are inclined 
towards a government where citizens should have a voice in politics (Font $e t$ al., 2015), rather than being a contradiction, this state of play reveals the importance of experts in a complex reality and the importance of being heard by politicians in a world where individuals have gained the right to have a say. The inclination towards meritocracy, shown by our groups, highlights the importance given to politics, rather than being a de-politicizing process, as suggested by Hibbing and Theiss-Morse, or an idea to go along with populism ideals. Politics has to do with the common rules, which are not easy to deal with. It requires knowledge and expertise; but not only that, it also requires a complex system of communication channels with representatives and between people themselves.

The idea of experts ruling, or anything which aims to overwhelm representative democracy, is finally rejected. Because politics matters and is complex, citizens think that experts cannot be left out, but neither can citizens. The debate has to take place in political institutions (from political parties to parliaments), but it shouldn't forget the state/society links. Presented with more than one model of involvement in everyday politics, participants support the idea of citizen debate on key political issues. As much of the research on political process preferences shows, the idea of referenda about important issues is widely shared, while specific participatory procedures such as participatory budgeting, participatory councils, etc., are common mainly to leftwing groups (García-Espín et al., 2017).

We think the focus groups illustrate an important point in the debate about political process preferences. Politicians, experts and people do not live in separate dimensions. As Font et al. (2015) suggested before, the three ideal political dimensions are not antagonistic and are intertwined in the minds of citizens. The compatibility between critical and stealth attitudes in people's minds highlights 1) the importance of expertise in politics and 2) the will to have more open political systems. Future research has important questions to ask in order to better understand how the three dimensions (expertise, participation and representation) are articulated and to make sense of the divergences between countries. We cannot forget the Spanish political disaffection context. Perhaps in other contexts we may expect different results. 


\section{References}

Baiocchi, G. and Ganuza, E. (2016). Popular democracy: The paradox of participation. Stanford: Stanford University Press.

Bengtsson, A. and M. Mattila (2009). Direct democracy and its critics: Support for direct democracy and stealth democracy in Finland". West European Politics, 32 (5), 10311048. Available in: https://doi.org/10.1080/01402380903065256.

Bengtsson, A. and Christensen, H. S. (2014). Ideals and Actions: Do citizens' patterns of political participation correspond to their conception of democracy? Government and Opposition, 51 (2), 234-260. Available in: https://doi.org/10.1017/gov.2014.29.

Bonet, E., Martin, I. and Montero, J. R. (2006). Las actitudes políticas de los españoles. In J. Font, J. R. Montero and M. Torcal (eds.). Ciudadanos, asociaciones y participación en España (pp. 105-132). Madrid: Centro de Investigaciones Sociológicas.

Boyatzis, R. E. (1998). Transforming qualitative information: Thematic analysis and code development. Thousand Oaks, London, New Delhi: SAGE.

Bryman, A. (2001). Social research methods. Oxford: Oxford University Press.

Committee of Ministers of the Council of Europe. (2001). Participation of citizens in local public life. Recommendation 2001-19.

Crozier, M., Huntington, S. P. and Watanuki, J. (1975). The crisis of democracy. New York: New York University Press.

Dalton, R. J. (2004). Democratic challenges, democratic choices: The erosion of political support in advanced industrial democracies. Oxford: Oxford University Press. Available in: https://doi.org/10.1093/acprof:oso/9780199268436.001.0001.

Easton, D. (1965). A systems analysis of political life. Chicago: University of Chicago Press.

Font, J., Navarro, C., Wojcieszak, M. and Alarcón, P. (2012). ¿ "Democracia sigilosa” en España?: preferencias de la ciudadanía española sobre las formas de decisión politica y sus factores explicativos. Madrid: Centro de Investigaciones Sociológicas.

Font, J. and Navarro, C. (2013). Personal experience and the evaluation of participatory instruments in Spanish cities. Public Administration, 91 (3), 616-631. Available in: ttps://doi.org/10.1111/j.1467-9299.2012.02106.x.

Font, J., Della Porta, D. and Sintomer, Y. (eds.) (2014). Participatory democracy in Southern Europe: Causes, characteristics and consequences. New York: Rowman and Littlefield.

Font, J., Wojcieszak, M. and Navarro, C. (2015). "Participation, representation and expertise: Citizen preferences for political decision-making processes". Political Studies, 63, 153-172.

Gamson, W. and Sifry, M. (2013). “The Occupy Movement”. The Sociological Quarterly, 54 (1), 159-230. Available in: https://doi.org/10.1111/tsq.12026.

García-Espín, P., Ganuza, E. and de Marco, S. (2017). ¿Asambleas, referéndum o consultas? Representaciones sociales de la participación ciudadana”. Revista Española de Investigaciones Sociológicas (forthcoming in 2017). Available in: https://doi.org/10.5477/cis/ reis. 157.45 .

Hibbing, J. R. and Theiss-Morse, E. (2002). Stealth democracy: Americans' beliefs about how Government should work. Cambridge: Cambridge University Press. Available in: https:// doi.org/10.1017/CBO9780511613722. 
Hydén, L. C. and Bülow, P. H. (2003). Who's talking: drawing conclusions from focus groupssome methodological considerations. International Journal Social Research Methodology, 6 (4), 305-321. Available in: https://doi.org/10.1080/13645570210124865.

Katz, R. S. and Mair, P. (1995). Changing models of party organization and party democracy: The emergence of the cartel party. Party Politics 1 (1), 5-28. Available in: https://doi.org /10.1177/1354068895001001001.

Kitzinger, J. (1995). Qualitative research. Introducing focus groups. BMJ: British medical journal, 311 (7000), 299-302.

Laclau, E. (2007). On Populist Reason. London: Verso.

Lasch, C. (1995). The revolt of the elites. New York: Norton Company.

McHugh, D. (2006). Wanting to be heard but not wanting to act? Addressing political disengagement”. Parliamentary Affairs, 59 (3), 546-552. Available in: https://doi.org/10.1093/ $\mathrm{pa} / \mathrm{gs} 1027$.

Morgan, D. L. (1996). Focus Group. Annual Review of Sociology, 22, 129-152. Available in: https://doi.org/10.1146/annurev.soc.22.1.129.

Mota, F. (2006). ¿Hacia la democracia participativa en España? Coincidencias y discrepancias entre ciudadanos y representantes políticos. En A. Martínez (ed.). Representación y calidad de la democracia en España. Madrid: Tecnos.

Munday, J. (2006). Identity in focus: The use of focus groups to study the construction of collective identity”.Sociology,40(1):89-105.Availablein:https://doi.org/10.1177/0038038506058436.

Neblo, M. A., Esterling, K., Kennedy, R., Lazer, D. and Sokhey, A. (2010). Who wants to deliberate and why? American Political Science Review, 104 (3), 566-583. Available in: https://doi.org/10.1017/S0003055410000298.

Norris, P. (1999). Critical citizens: Global support for democratic government: Global support for democratic government. Oxford: Oxford University Press. Available in: https://doi.org/1 0.1093/0198295685.001.0001.

— (2009). Public disaffection and electoral reform: Pressure from below? Paper prepared for ECPR Joint Sessions of Workshops, Lisbon, 14-19 April 2009.

Norris, P., Walgrave, S. and Van Aelst, P. (2006). Does protest signify disaffection? Demonstrators in a postindustrial democracy. In M. Torcal and J. R. Montero (eds.). Political dissatisfaction in contemporary democracies (pp. 279-307). London and New York: Routledge.

Pharr, S. and Putnam, R. (2000). Disaffected democracies. Princeton: Princeton University Press.

Sirianni, C. and Friedland, L. (2001). Civic innovation in America: Community empowerment, public policy, and the movement for civic renewal. Oakland: University of California Press.

Smithson, J. (2000). Using and analyzing focus groups: limitations and possibilities. International Journal of Social Research Methodology, 3 (2), 103-11. Available in: https://doi. org/10.1080/136455700405172.

Stoker, G. (2006). Why politics matters: Making democracy work. London: Palgrave Macmillan.

Tejerina, B., Perugorría, I., Benski, T. and Langman, L. (2013). From indignation to occupation: A new wave of global mobilization. Current Sociology, 61, 377-392. Available in: https://doi.org/10.1177/0011392113479738.

Torcal, M. (2014). The decline of political trust in Spain and Portugal: Economic performance or political responsiveness? American Behavioral Scientist, 58: 1542-1567. Available in: https://doi.org/10.1177/0002764214534662. 
Torcal, M. and Montero, J. R. (eds.) (2006). Political disaffection in contemporary democracies: Social capital, institutions, and politics. London: Routledge.

Webb, P. (2013). Who is willing to participate? Dissatisfied democrats, stealth democrats and populists in the United Kingdom. European Journal of Political Research, 52, 747-772. Available in: https://doi.org/10.1111/1475-6765.12021. 